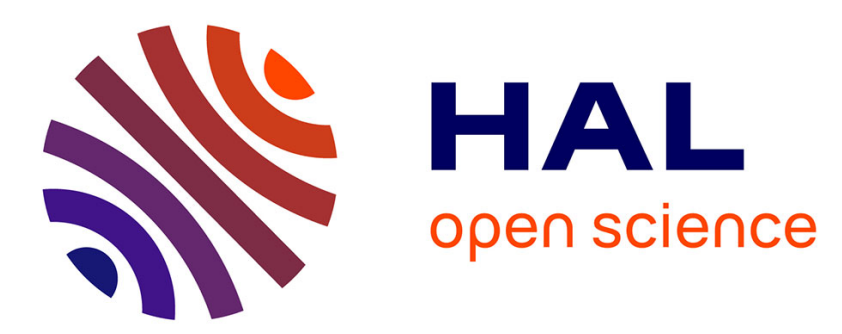

\title{
PRODUCTIVITY AND EFFICIENCY CHANGE AND SHAREHOLDER VALUE: EVIDENCE FROM THE SPANISH BANKING SECTOR
}

Carmelo Reverte, Isidoro Guzman

\section{- To cite this version:}

Carmelo Reverte, Isidoro Guzman. PRODUCTIVITY AND EFFICIENCY CHANGE AND SHAREHOLDER VALUE: EVIDENCE FROM THE SPANISH BANKING SECTOR. Applied Economics, 2008, 40 (15), pp.2037-2044. 10.1080/00036840600949413 . hal-00582079

\section{HAL Id: hal-00582079 \\ https://hal.science/hal-00582079}

Submitted on 1 Apr 2011

HAL is a multi-disciplinary open access archive for the deposit and dissemination of scientific research documents, whether they are published or not. The documents may come from teaching and research institutions in France or abroad, or from public or private research centers.
L'archive ouverte pluridisciplinaire HAL, est destinée au dépôt et à la diffusion de documents scientifiques de niveau recherche, publiés ou non, émanant des établissements d'enseignement et de recherche français ou étrangers, des laboratoires publics ou privés. 


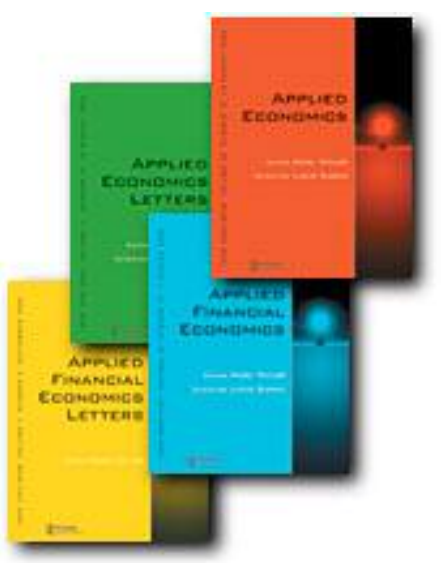

PRODUCTIVITY AND EFFICIENCY CHANGE AND SHAREHOLDER VALUE: EVIDENCE FROM THE SPANISH BANKING SECTOR

\begin{tabular}{|r|l|}
\hline Journal: & Applied Economics \\
\hline Manuscript ID: & APE-06-0112 \\
\hline Journal Selection: & Applied Economics \\
\hline JEL Code: & $\begin{array}{l}\text { G21 - Banks|Other Depository Institutions|Mortgages }<\text { G2 - } \\
\text { Financial Institutions and Services < G - Financial Economics, D24 - } \\
\text { Production |Capital and Total Factor Productivity|Capacity }<\text { D2 - } \\
\text { Production and Organizations < D - Microeconomics }\end{array}$ \\
\hline Keywords: & $\begin{array}{l}\text { Productivity change, Malmquist index, DEA, Banking, Shareholder } \\
\text { value }\end{array}$ \\
\hline
\end{tabular}

powered by ScholarOne

Manuscript Central ${ }^{\mathrm{M}}$ 


\title{
PRODUCTIVITY AND EFFICIENCY CHANGE AND SHAREHOLDER VALUE: EVIDENCE FROM THE SPANISH BANKING SECTOR
}

\author{
Isidoro Guzmán and Carmelo Reverte
}

Technical University of Cartagena

Faculty of Business Sciences

Department of Accounting and Finance

Paseo Alfonso XIII, 50 (30203) Cartagena (Spain)

\begin{abstract}
:
Productivity change and shareholder value have been analysed in the banking sector in the last few years, although it should be noted that these two important aspects have been studied separately. In this regard, the main contribution of our study is to link these two lines of research by verifying whether those banks characterised by higher levels of efficiency and productivity change have a higher shareholder value. To measure changes in efficiency and productivity we use the Malmquist non-parametric technique, which is calculated from Data Envelopment Analysis (DEA) linear programming approach. The Malmquist total factor productivity index enables separation of the 'catching up' effect, i.e, changes over time in technical efficiency, from 'technological change', i.e., the shift of best practice frontier over time due to technological progress. Our results for a sample of listed Spanish banks in the period 2000-2004 confirm that those banks with higher efficiency and productivity changes have a higher shareholder value, even after controlling for the impact of traditional measures of performance, such as return on assets.
\end{abstract}

Running title: Productivity and shareholder value

Corresponding author's E-mail: Carmelo.Reverte@upct.es

February 2006 


\section{PRODUCTIVITY AND EFFICIENCY CHANGE AND SHAREHOLDER VALUE: EVIDENCE FROM THE SPANISH BANKING SECTOR}

\section{INTRODUCTION}

Given the importance of the banking sector for the whole economy in general, and for the financial system in particular, a number of studies have analysed the efficiency of this sector since the early 1990s in order to assess the impact of the structural changes to which it has been subjected such as deregulation, liberalisation, introduction of new technologies and adaptation to the European Community's directives. The main literature has focused on analysing cost efficiency, using both parametric and non-parametric methodologies (see Berger and Humphrey, 1997 and Goddard et al., 2001, for extensive surveys). However, a criticism of these efficiency studies relates to the fact that the empirical results may not account for both technological and efficiency change through time, that is, the analyst may end up without learning whether efficiency improves or deteriorates over time if efficiency is only measured with respect to a year-specific period (Hunter and Timme, 1991). To overcome this problem, a number of recent studies have focused on investigating productivity change, mainly by employing non-parametric methodologies such as the Malmquist Total Factor Productivity Index approach (e.g., Alam, 2001; Chaffai et al., 2001), which is calculated from efficiency scores based on Data Envelopment Analysis (DEA) linear programming approach. This Malmquist index technique enables separation of the 'catching up' or 'efficiency change' effect, i.e, changes over time in the technical efficiency of each decision making unit with respect to best practice frontier, from 'technological change', i.e., the shift of best practice frontier over time due to technological progress.

On the other hand, given the current importance of shareholder value maximisation as a key objective for financial institutions, another strand of recent research (e.g., Fiordelisi and Molyneux, 2006) has analysed shareholder value in European banking and its relationship with several performance indicators (such as return on assets, economic value added, etc.). 
However, to the best of our knowledge, so far there is no study that links the aforementioned two lines of research focused on productivity and efficiency change and shareholder value. In this regard, the main contribution of our study is to verify whether those banks characterised by higher efficiency and productivity changes have a higher shareholder value, proxied by total shareholder return (Rappaport, 1986). This measure captures the two sources of value creation for a typical shareholder, i.e., the increase in share price during the year and the dividends received in that year.

We focus our analysis on the Spanish banking industry which, according to the Spanish Banking Association (2002), plays a prominent role in European banking based on the value of the most relevant performance ratios. Over the last two decades, the Spanish banking industry, likewise many other Western European banking systems, has experienced fascinating changes, such as deregulation, liberalisation, and technological advances, which have significantly reshaped the industry. The period under study is 2000-2004, which follows the wave of mergers and acquisitions that took place in Spain in the 1990s.

The rest of the paper is structured as follows. Section 2 describes the methodology used for measuring productivity -the Malmquist Total Factor Productivity (TFP) Index approach-. Section 3 presents the research design including the model for measuring the performance of the banks, the selection of outputs and inputs, and the data used for the empirical application. Section 4 comprises the results of the empirical study. Finally, section 5 concludes the paper.

\section{MALMQUIST TOTAL FACTOR PRODUCTIVITY INDEX}

Total factor productivity (TFP) measures changes in total output relative to inputs and the concept derives from the ideas of Malmquist (1953). The non-parametric Malmquist total factor productivity index, developed from Caves et al. (1982), has been the most commonly used measure of productivity change (see Färe et al., 1997 for a survey) ${ }^{1}$. The Malmquist index is based on the output distance function which, following Shepard (1970) and Färe et al. (1994), is defined as:

\footnotetext{
${ }^{1}$ Other studies measure productivity change using a parametric approach (Berger and Mester, 1999, 2001). However, Casu et al. (2004), in their analysis of productivity change in European banking
} 


$$
D_{0}^{t}\left(x_{t}, y_{t}\right)=\inf \left\{\theta:\left(x_{t}, y_{t} / \theta\right) \in S^{t}\right\}
$$

where $x_{t}$ and $y_{t}$ denote a vector of inputs and outputs respectively, and $S^{t}$ represents the production technology for each reference period. The distance function is the reciprocal of Farrell's (1957) measure of output technical efficiency, which calculates how far an observation is from the frontier of technology.

To define the Malmquist productivity index, it is necessary to define the above distance function with respect to two different time periods. Following Färe et al. (1994), assuming constant returns to scale (CRS) and an output orientation, the Malmquist TFP index between period $s$ (the base period) and period $t$ is given by:

$$
M_{0}\left(y_{s}, x_{s}, y_{t}, x_{t}\right)=\left[\frac{D_{0}^{s}\left(x_{t}, y_{t}\right)}{D_{0}^{s}\left(x_{s}, y_{s}\right)} \times \frac{D_{0}^{t}\left(x_{t}, y_{t}\right)}{D_{0}^{t}\left(x_{s}, y_{s}\right)}\right]^{1 / 2}
$$

where the notation $\left[D_{0}^{s}\left(x_{t}, y_{t}\right)\right]$ represents the distance from the period $t$ observation to the period $s$ technology or efficiency frontier.The previous formulation in (2) is, in fact, a geometric mean of two TFP indices, the first evaluated with respect to period $s$ technology and the second with respect to period $t$ technology. A value of of $M_{0}$ greater than one will indicate a growth in productivity from period $s$ to period $t$, while a value less than one will indicate a decline in productivity.

The Malmquist index formulation of productivity growth can be further broken down into the following two components:

$$
M_{0}\left(y_{s}, x_{s}, y_{t}, x_{t}\right)=\left[\frac{D_{0}^{t}\left(x_{t}, y_{t}\right)}{D_{0}^{s}\left(x_{s}, y_{s}\right)}\right] \times\left[\frac{D_{0}^{s}\left(x_{t}, y_{t}\right)}{D_{0}^{t}\left(x_{t}, y_{t}\right)} \times \frac{D_{0}^{s}\left(x_{s}, y_{s}\right)}{D_{0}^{t}\left(x_{s}, y_{s}\right)}\right]^{1 / 2}
$$


The first component of productivity change is referred to as technical efficiency change $^{2}$, and measures the change in the efficiency of a decision making unit (DMU) relative to the best practice frontier, that is, the change in the DMU's distance to the production frontier. Thus, a value greater than 1 indicates an increase in the efficiency relative to the frontier while a value less than 1 indicates a decline in efficiency with respect to the frontier. The second component, referred to as technological change, is due to the variation of the production frontier between two periods, and thus reflects the improvement or deterioration of best practice DMUs. A value greater than 1 indicates technological progress while a value less than 1 means technological deterioration. The usefulness of this decomposition is that it provides information on the sources of the overall productivity change.

Following Färe et al. (1994), we can calculate the required distance measures involved in equation (3) for the Malmquist TFP index by using Data Envelopment Analysis (DEA)-like linear programming techniques ${ }^{3}$, which is the method that will be followed in our empirical analysis. Under the assumption of $\mathrm{CRS}^{4}$, the DEA model can be expressed mathematically as follows:

$$
\begin{gathered}
D_{0}^{t}\left(x_{t}, y_{t}\right)^{-1}=\max _{\phi, \lambda} \phi \\
\text { s.t. } \quad \\
-\phi y_{i t}+Y_{t} \lambda \geq 0 \\
x_{i t}-X_{t} \lambda \geq 0 \\
\lambda \geq 0
\end{gathered}
$$

\footnotetext{
${ }^{2}$ A further decomposition of the 'technical efficiency change' component to take into account variable returns to scale (VRS) technology has been proposed, which distinguishes between 'scale efficiency' and 'pure technical efficiency change' (Färe et al., 1994). However, this further decomposition has been subjected to a number of criticisms (see, e.g., Ray and Desli, 1997). In this regard, there seems to be consensus that the Malmquist index is correctly measured by the ratio of the CRS distance function even when the technology exhibits VRS (Casu et al., 2004).

${ }^{3}$ DEA is a technique originally introduced by Charnes et al. (1978) as a reformulation of Farrell's (1957) efficiency measure to the multiple-output, multiple-input case. This technique has been usually applied to evaluate efficiency in different economic sectors, specially for financial institutions (see Berger and Humprey, 1997 for a survey).

${ }^{4}$ The hypothesis of constant returns to scale was subsequently modified to allow for variable returns to scale (VRS) (Banker et al., 1984), which is the most commonly used specification in the 1990s, because the CRS assumption is only appropiate when all DMUs are operating at an optimal scale. The VRS approach provides technical efficiency scores that are greater than or equal to those obtained using the CRS model.
} 
where $Y_{t}$ and $X_{t}$ represent the vector of outputs and inputs, respectively and $\lambda$ defines the weight of each unit within the reference or 'peer' group to which is compared any particular observation in order to determine the distance to the efficient frontier ${ }^{5}$.

\section{DATA AND VARIABLES}

\section{Sample and data sources}

As our dependent variable -total shareholder return- is computed from market share prices, we consider Spanish banks listed in the Madrid Stock Exchange on the fiveyear period 2000-2004, which follows the wave of mergers and acquisitions that took place in Spain in the 1990s. The list of the 14 quoted banks is reported in Table 1. Inputs and outputs necessary to compute efficiency and productivity measures are based on data from balance sheets and income statements collected from the website of the Spanish Securities Commission (www.cnmv.es). Regarding information on share prices and dividends, data come from Global Vantage Compustat.

\begin{tabular}{ll}
\hline Table 1. Sample Banks & \\
\hline Banco Bilbao Vizcaya Argentaria, SA & Banco de Vasconia, SA \\
Banco de Andalucía, SA & Banco Español de Crédito, SA \\
Banco de Castilla, SA & Banco Guipuzcoano, SA \\
Banco de Crédito Balear, SA & Banco Pastor, SA \\
Banco de Galicia, SA & Banco Popular Español, SA \\
Banco de Sabadell, SA & Banco Santander Central Hispano, SA \\
Banco de Valencia, SA & Bankinter, SA \\
\hline
\end{tabular}

\section{Input and output definition}

The output and input selection becomes a crucial issue for research into cost efficiency. This is particularly true for banks as there is no agreement on appropiate inputs and outputs in this industry ${ }^{6}$. As Berger and Humphrey (1997) point out, although there is no perfect approach, the intermediation approach may be more appropiate for evaluating entire financial institutions because this approach is

\footnotetext{
${ }^{5}$ The DEA models can take two different orientations. The first one, called input orientation, seeks to identify technical inefficiency as a proportional reduction in inputs usage. The second one, referred to as output orientation, seeks to identify technical inefficiency as a proportional increase in output production. To date, the theoretical literature is inconclusive as to the best choice among these two alternatives. These two orientations yield equal values under CRS, but not when VRS is assumed (Thanassoulis, 2001).

${ }^{6}$ The most debated issue regards the role of deposits. Under the production model, which views banks as service-producing organisations, deposits are considered as an output. Under the intermediation approach, banks are viewed as financial intermediaries whose primary business is to borrow funds from savers and lend those funds to customers to obtain profits. Hence, in this case deposits are regarded as inputs.
} 
inclusive of interest expenses, which often account for one-half to two-thirds of total costs. Thus, following the empirical literature (Molyneux et al., 1996; Mester, 1996, Yeh, 1996), the intermediation approach is used, which views banks as mediators between the demand and supply of funds. Therefore, two banks' outputs are used in the current study: total loans $\left(k_{1}\right)$ and interest income and commissions received $\left(k_{2}\right)$. In the input side, three variables are selected: total deposits $\left(k_{3}\right)$, interests expenses and commissions paid $\left(k_{4}\right)$ and personnel and administration expenses $\left(k_{5}\right)^{7}$. Table 2 shows the descriptive statistics of the outputs and inputs considered in the design of performance models.

Table 2. Summary Descriptive Statistics for outputs and inputs

\begin{tabular}{llccccc}
\hline \multirow{2000}{*}{} & $\mathbf{K}_{\mathbf{1}}$ & $\mathbf{K}_{\mathbf{2}}$ & $\mathbf{K}_{\mathbf{3}}$ & $\mathbf{K}_{\mathbf{4}}$ & $\mathbf{K}_{\mathbf{5}}$ \\
& Mean & 28348 & 4752 & 29260 & 2811 & 1138 \\
& Median & 4805 & 412 & 4493 & 196 & 143 \\
& St.dev. & 53862 & 10363 & 56719 & 6547 & 2348 \\
$\mathbf{2 0 0 1}$ & & & & & \\
& Mean & 30825 & 5076 & 31810 & 2728 & 1293 \\
& Median & 5547 & 498 & 4840 & 243 & 152 \\
& St. dev. & 56461 & 10716 & 60854 & 6022 & 2689 \\
$\mathbf{2 0 0 2}$ & Mean & 30513 & 4277 & 29638 & 2078 & 1158 \\
& Median & 6340 & 473 & 5223 & 172 & 159 \\
& St. dev. & 52712 & 8792 & 54833 & 4533 & 2319 \\
& & & & & & \\
$\mathbf{2 0 0 3}$ & Mean & 33452 & 3527 & 29411 & 1509 & 1044 \\
& Median & 7754 & 480 & 5886 & 142 & 162 \\
& St. dev. & 55554 & 6875 & 52174 & 3171 & 2033 \\
& & & & & & \\
$\mathbf{2 0 0 4}$ & Mean & 49141 & 3730 & 40808 & 1581 & 1083 \\
& Median & 9866 & 550 & 6958 & 163 & 171 \\
& St. dev. & 93430 & 7222 & 82097 & 3312 & 2072 \\
\hline
\end{tabular}

Notes: $\mathrm{K}_{1}=$ total loans; $\mathrm{K}_{2}=$ interests income and commissions received; $\mathrm{K}_{3}=$ total deposits; $\mathrm{K}_{4}=$ interests expenses and commissions paid; $\mathrm{K}_{5}=$ personnel and administration expenses (variables are expressed in million ).

\section{EMPIRICAL RESULTS}

\section{DEA efficiency scores}

To get an overview of the efficiency annual measures, Table 3 summarises the results for three different models. The first one is based on the hypothesis of constant returns to scale (CRS), while the two remaining models assume the hypothesis of

\footnotetext{
${ }^{7}$ To run the DEA model, personnel expenses and administration expenses have been summarised into a single variable in order to avoid an excessive number of inputs so that the proposed model can be accepted regarding the total number of variables (El-Mahgary and Ladhelma, 1995).
} 
variable returns to scale (VRS) under a double specification (input/output orientation). A value of the DEA score equal to one means efficiency while a value less than one means inefficiency.

\begin{tabular}{ccccccc}
\hline \multicolumn{2}{l}{ Table 3. DEA efficiency scores } \\
\hline & \multicolumn{1}{c}{ Constant returns to scale } & \multicolumn{4}{c}{ Variable returns to scale } \\
\cline { 2 - 7 } & & & \multicolumn{2}{c}{ Output-based } & \multicolumn{2}{c}{ Input-based } \\
\hline Period & Mean & St. Dev. & Mean & St. Dev. & Mean & St.Dev. \\
\hline 2000 & 0.907 & 0.112 & 0.952 & 0.090 & 0.948 & 0.100 \\
2001 & 0.934 & 0.083 & 0.973 & 0.045 & 0.972 & 0.047 \\
2002 & 0.915 & 0.110 & 0.947 & 0.084 & 0.944 & 0.088 \\
2003 & 0.906 & 0.107 & 0.959 & 0.093 & 0.960 & 0.090 \\
2004 & 0.912 & 0.107 & 0.960 & 0.085 & 0.959 & 0.087 \\
\hline
\end{tabular}

All models show high efficiency scores for all years, which implies that the process of mergers and acquisitions occurred in Spain during the 1990s have resulted in an improvement of the efficiency of the resulting banks. For the CRS model, the average efficiency score shows a slight improvement in the efficiency level over time $(+0.5 \%)$. Regarding the VRS model, the improvement in the efficiency level over time is very similar $(+0.8 \%$ for the output-based model and $+1.1 \%$ for the inputbased model). Figure 1 depicts the evolution of DEA efficiency scores over the sample period.

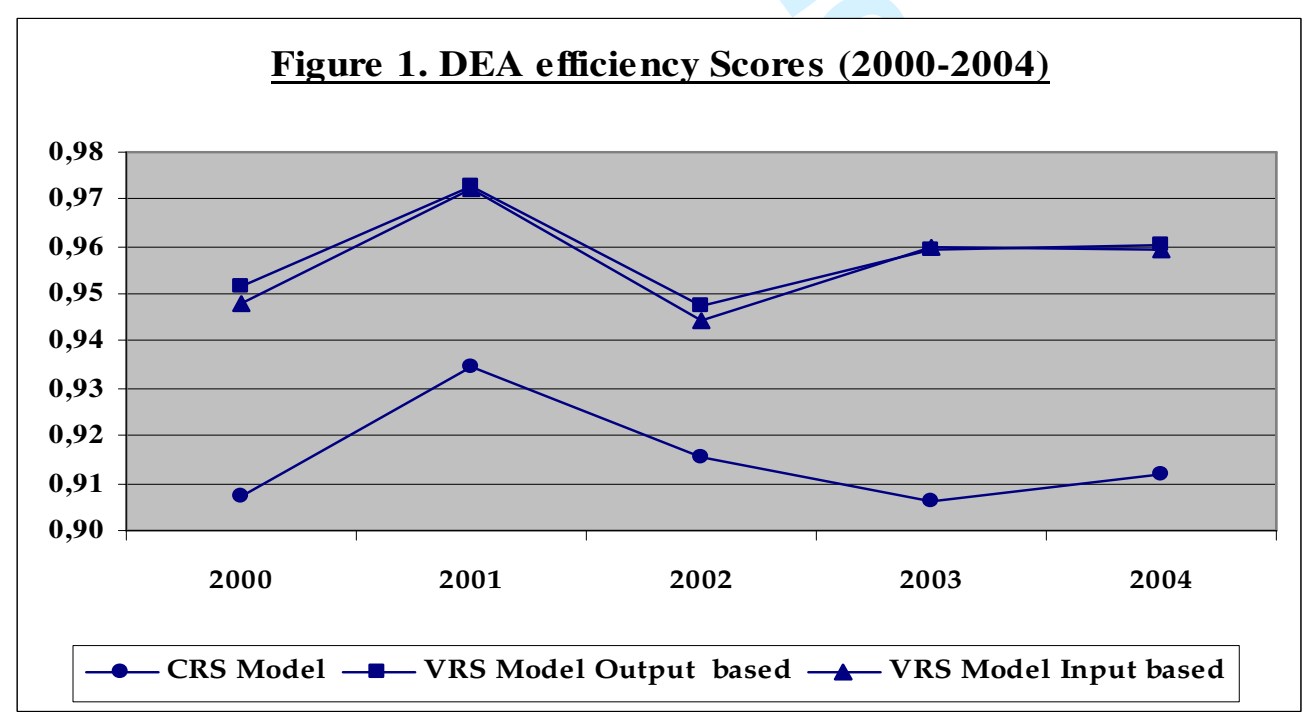




\section{Malmquist Index estimates}

The results from the efficiency measures analysis support that efficiency scores have increased slightly over our sample period. However, this trend in mean efficiency values cannot be used to infer productivity growth because they do not take into account shifts in the efficiency frontier, that is, shifts in best practice firms. Considering this issue, Malmquist total factor productivity change (TFP) is computed to evaluate productivity growth. We further decompose TFP into its two components: a) technological change (TC), or change in best practice, and b) 'catching-up' or technical efficiency change (TEC), where TFP $=$ TC $x$ TEC. Table 4 summarises geometric means of results for individual banks for each two-year period -also depicted in Figure 2- and the last row shows the geometric mean of the annual means for the entire period (2000-2004).

\begin{tabular}{cccc}
\hline Table 4. Malmquist Index decomposition & (summary of annual geometric means) \\
\hline & $\begin{array}{c}\text { Technical } \\
\text { Efficiency Change }\end{array}$ & $\begin{array}{c}\text { Technological } \\
\text { Change }\end{array}$ & $\begin{array}{c}\text { Total Factor } \\
\text { Productivity Change }\end{array}$ \\
Years & (TEC) & (TC) & (TFP) \\
\hline $2000 / 2001$ & 1.034 & 0.989 & 1.022 \\
$2001 / 2002$ & 0.976 & 1.049 & 1.024 \\
$2002 / 2003$ & 0.990 & 1.068 & 1.058 \\
$2003 / 2004$ & 1.006 & 0.981 & 0.987 \\
\hline $\mathbf{2 0 0 0 / 2 0 0 4}$ & $\mathbf{1 . 0 0 1}$ & $\mathbf{1 . 0 2 1}$ & $\mathbf{1 . 0 2 2}$ \\
\hline
\end{tabular}

Our results reveal a productivity growth in the sample period $(+2.2 \%)$, which is almost entirely attributable to technological change $(+2.1 \%)$. This finding is consistent with the results obtained by Mukherjee et al. (2001) for the US case and Asmild et al. (2004) for the Canadian case. Technical efficiency change shows almost no growth $(+0.1 \%)$, which implies that, despite the gains achieved by best practice banks, there has been little catching-up effect on the part of the remaining banks. 


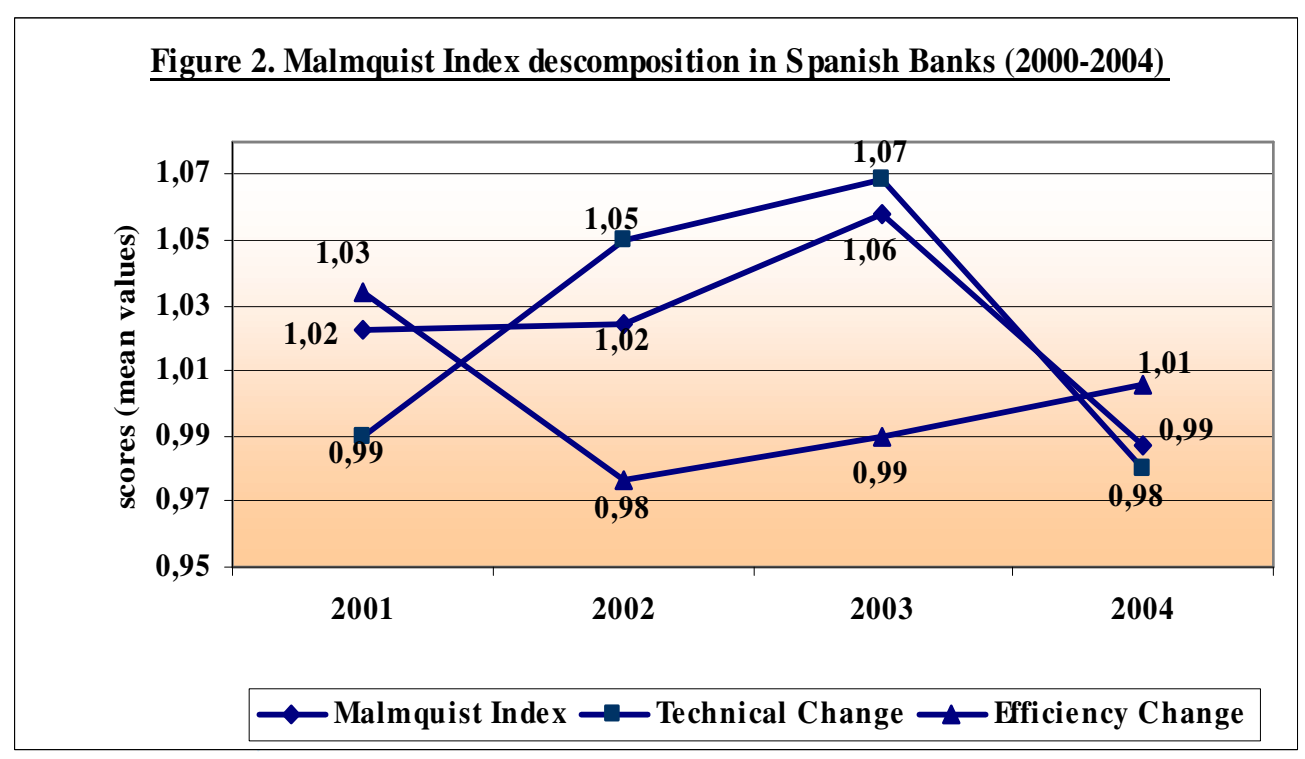

Relationship between shareholder value and change in efficiency and productivity

Our main hypothesis is that those banks characterised by a higher efficiency change and a higher total productivity change should have a higher shareholder value, proxied by total shareholder return (Rappaport, 1986). Total shareholder return (TSR) is computed for each bank as follows:

$$
T S R_{i t}=\frac{P_{i t}-P_{i t-1}+d_{i t}}{P_{i t-1}}
$$

where $\mathrm{P}_{\mathrm{it}}$ is price of bank $i$ 's shares at the end of year $t, \mathrm{P}_{\mathrm{it}-1}$ is price of bank $i$ 's shares at the beginning of year $t$ and $\mathrm{d}_{\mathrm{it}}$ are dividends paid by bank $i$ in year $t$. Therefore, TSR captures the two sources of value creation for a shareholder, i.e., the increase in share price during the year and the dividends received in that year.

To test our hypothesis, we first perform a cluster analysis in order to form two groups of banks according to their values of the technical efficiency change variable (TEC) and the total productivity change variable (TFP). Then we compute TSR for each group of banks and test whether the difference in TSR between the two groups is statistically significant. 
Table 5 reports the results for the $k$-means cluster analysis, which clearly differentiates two groups of banks. The first cluster includes those banks with growth in total productivity (mean $\mathrm{TFP}=1.077$ ) and with an increase in efficiency with respect to best practice frontier (mean TEC $=1.028$ ), while the second cluster groups those banks with a decline in total productivity (mean $\mathrm{TFP}=0.906)$ and with a decrease in efficiency with respect to best practice frontier (mean TEC=0.945).

As hypothesised, it can be observed in Table 5 that the TSR is higher for those banks pertaining to cluster $1(15.56 \%)$ as compared to those pertaining to cluster $2(4.03 \%)$, this difference been statistically significant at a $5 \%$ level $(p$-value $=0.0223)$. Therefore, it seems that the shareholder value creation is higher in those banks characterised by higher efficiency and productivity changes from one period to another.

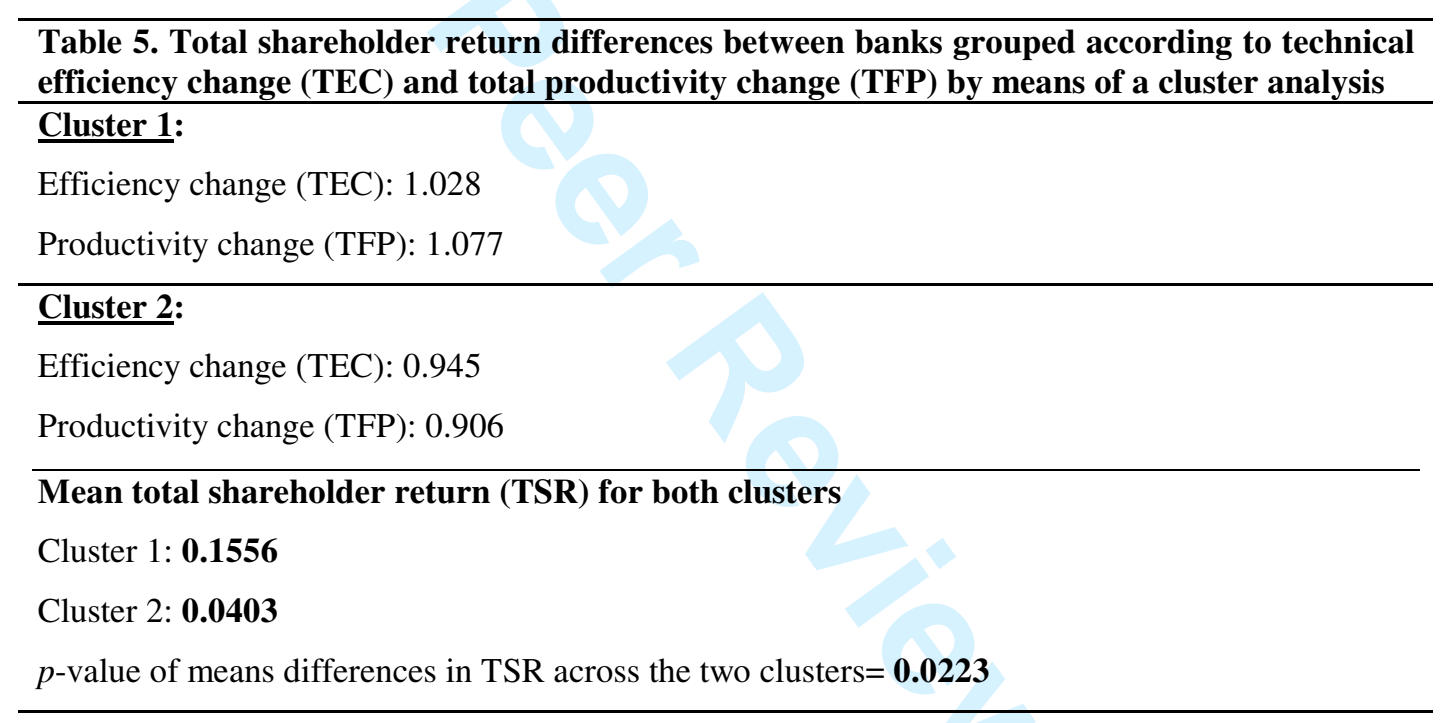

However, it could be the case that those banks with higher efficiency and productivity changes have higher shareholder returns just because they have higher return on assets (ROA) -which is a common accounting-based measure of banks' performance-. In order to verify whether our measures of efficiency and productivity change are significantly related to TSR after controlling for the effect of ROA we estimate for our panel data set the following three models:

$$
\begin{aligned}
& \mathrm{TSR}_{\mathrm{it}}=\alpha_{0}+\alpha_{1} \mathrm{ROA}_{\mathrm{it}}+\mathrm{u}_{\mathrm{it}} \\
& \mathrm{TSR}_{\mathrm{it}}=\beta_{0}+\beta_{1} \mathrm{ROA}_{\mathrm{it}}+\beta_{2} \mathrm{TEC}_{\mathrm{it}}+\mathrm{u}_{\mathrm{it}} \\
& \mathrm{TSR}_{\mathrm{it}}=\gamma_{0}+\gamma_{1} \mathrm{ROA}_{\mathrm{it}}+\gamma_{2} \mathrm{TFP}_{\mathrm{it}}+\mathrm{u}_{\mathrm{it}}
\end{aligned}
$$


where:

$\mathrm{TSR}_{\mathrm{it}}$ : Total shareholder return of bank $\mathrm{i}$ for period $\mathrm{t}$.

$\mathrm{ROA}_{\mathrm{it}}$ : Return on assets of bank i for period $\mathrm{t}$.

TEC: Technical efficiency change of bank $i$ for period $t$.

TFP: Malmquist's total productivity change of bank i for period $t$.

We hypothesise that ROA, TEC and TFP should be positively and significantly associated with TSR. Table 6 shows the results from the estimation of models (6), (7) and (8). As we work with panel data, we can have two alternative specifications, i.e., the fixed effects model and the random effects model. The former assumes differences in intercepts across firms, whereas the latter assumes differences in the error term. The Hausman (1978) specification test compares the fixed versus random effects under the null hypothesis that the individual effects are uncorrelated with the other regressors in the model. If the null is rejected (i.e., there is correlation among individual effects and regressors), the random effect model produces biased estimators, so a fixed effect model is preferred. In our case, the Hausman test (1978) reveals that the random effects specification (which is estimated using Generalized Least Squares) is better than the fixed effects specification for the three models. 


\begin{tabular}{|c|c|c|c|c|c|}
\hline \multicolumn{6}{|c|}{ Dependent variable: TSR } \\
\hline Model & Intercept & ROA & TEC & TFP & $\mathrm{R}^{2}$ \\
\hline Model (6) & $\begin{array}{c}-0.006 \\
(0.995)\end{array}$ & $\begin{array}{c}11.467^{* *} \\
(0.013)\end{array}$ & & & 0.0907 \\
\hline Model (7) & $\begin{array}{c}-0.443 \\
(0.153)\end{array}$ & $\begin{array}{c}11.389^{* *} \\
(0.012)\end{array}$ & $\begin{array}{c}0.435^{*} \\
(0.075)\end{array}$ & & 0.1265 \\
\hline Model (8) & $\begin{array}{l}-0.554^{* * *} \\
(0.023)\end{array}$ & $\begin{array}{c}10.745^{* *} \\
(0.014)\end{array}$ & & $\begin{array}{c}0.541^{* * * *} \\
(0.010)\end{array}$ & 0.1807 \\
\hline
\end{tabular}

Notes: Figures in parentheses represent the $p$-values. TSR $_{\mathrm{it}}$ : Total shareholder return of bank $\mathrm{i}$ for period $t$; $\mathrm{ROA}_{\mathrm{it}}$ : Return on assets of bank $\mathrm{i}$ for period $\mathrm{t}$; TEC: Technical efficiency change of bank i for period t; TFP: Total productivity change of bank i for period $t$.

The results correspond to the random effects specification since the Hausman (1978) test indicates that this specification is better than the fixed effects model for the three models.

(*)Significant at the $10 \%$ level; (**)Significant at the 5\% level; (***)Significant at the $1 \%$ level.

As hypothesised, ROA, technical efficiency change (TEC) and productivity change (TFP) are positively and significantly related to TSR, being the latter (TFP) the most significant variable $(p$-value $=0.010)$. Moreover, the two variables analysed in our study (TEC and TFP) are significantly associated with TSR, even after controlling for the effect of ROA, leading to an increase in $\mathrm{R}^{2}$ of $3.58 \%$ and $9 \%$, respectively with respect to model (6). Therefore, we can assert that the impact of both efficiency and productivity change on shareholder value does not stem from the fact that they are subsumed in the ROA standard measure of banks' performance. Moreover, as expected, the total productivity change variable (TFP) has a greater impact on TSR with respect to the efficiency change variable (TEC) (0.54 vs 0.43 ), since the former also takes into account technological change over time.

\section{CONCLUSIONS}

Productivity change and shareholder value have been analysed in the banking sector in the last few years. However, these two important aspects have been studied separately. In this regard, the main contribution of our study is to link these two lines of research by verifying whether those banks characterised by higher levels of 
efficiency and productivity change have a higher shareholder value, proxied by total shareholder return (Rappaport, 1986). To measure changes in efficiency and productivity we use the Malmquist non-parametric technique, which is calculated from efficiency scores based on Data Envelopment Analysis (DEA) linear programming approach. This Malmquist index technique enables separation of the 'catching up' or 'efficiency change' effect, i.e, changes over time in the technical efficiency of each decision making unit with respect to best practice frontier, from 'technological change', i.e., the shift of best practice frontier over time due to technological progress.

Our results for a sample of listed Spanish banks in the period 2000-2004 confirm that those banks with higher efficiency and productivity changes have a higher shareholder value, even after controlling for the impact of traditional measures of performance, such as return on assets. 


\section{REFERENCES}

Alam, I. (2001) A non-parametric approach for assessing productivity dynamics of large US banks, Journal of Money, Credit, and Banking 33, 121-139.

Asmild, M., Paradi, J., Aggarwal, V. and Schaffnit, C. (2004) Combining DEA window analysis with the Malmquist index approach in a study of the Canadian banking industry", Journal of Productivity Analysis, 21 (1), 67-89.

Banker, R.D., Charnes, A. and Cooper, W.W. (1984) Some models for estimating technical and scale inefficiencies in Data Envelopment Analysis, Management Science, 30, 1078-1092.

Berger, A.N. and Humphrey, D.B. (1997) Efficiency of financial institutions: international survey and directions for future research, European Journal of Operational Research, 98, 175-212.

Berger, A.N. and Mester, L.J. (1999) What Explains the Dramatic Changes in Cost and Profit Performance of the US Banking Industry?, Working paper Federal Reserve Bank of Philadelphia No.1, February.

Berger, A.N. and Mester, L.J. (2001) Explaining the Dramatic Changes in Performance of US Banks: Technological Change, Deregulation and Dynamic Changes in Competition, Working paper Federal Reserve Bank of Philadelphia No.6, April.

Casu, B., Girardone, C. and Molyneux, P. (2004) Productivity change in European banking: A comparison of parametric and non-parametric approaches, Journal of Banking and Finance, 28, 2521-2540.

Caves, D.W., Christensen, L.R. and Diewert, W. (1982) The economic theory of index numbers and the measurement of input, output and productivity, Econometrica, 50, 1393-1414.

Chaffai, M.E., Dietsch, M. and Lozano-Vivas, A. (2001) Technological and environmental differences in the European banking industries, Journal of Financial Services Research, 19, 147-162.

Charnes A., Cooper W.W. and Rhodes, E. (1978) Measuring the efficiency of decision making units, European Journal of Operational Research, 2, 429-444.

El-Mahgary, S. and Ladhelma, R. (1995) Data Envelopment Analysis: visualizing the results, European Journal of Operational Research, 85, 700-710.

Färe, R., Grosskopf, S., Norris, M. and Zhang, Z. (1994) Productivity growth, technical progress and efficiency changes in industrialised countries, American Economic Review, 84, 66-83. 
Färe, R., Grosskopf, S. and Roos P. (1997). Malmquist Productivity Indexes: A Survey of Theory and Practice. In: Färe, R., Grosskopf, S., Russell, R.R. (Eds.), Index numbers: Essays in honour of Sten Malmquist. Kluwer Academic Publishers, Boston.

Farrell, M. J. (1957) The measurement of productive efficiency, Journal of the Royal Statistical Society, 120, 253-2891.

Fiordelisi, F. and Molyneux, P. (2006): Shareholder value in banking, Studies in Banking and International Finance, Palgrave MacMillan.

Goddard, J. A., Molyneux, P. and Wilson, J. O. S. (2001). European Banking: Efficiency, Technology and Growth. John Wiley \& Sons.

Hausman, J.A. (1978) Specification tests in econometrics, Econometrica, 46, 12511271.

Hunter, W.C. and Timme, S.G. (1991) Technological change in large US commercial banks, Journal of Business, 3, 339-62.

Malmquist, S. (1953) Index numbers and indifference curves. Trabajos de Estadística, 4, 209-242.

Mester, L. J. (1996) A study of bank efficiency: taking into account risk-preferences, Journal of Banking and Finance, 20, 389-405.

Molyneux, P., Altunbas, Y. and Gardener, E.P.M. (1986) Efficiency in European banking, John Wiley \& Sons, Chichester, England.

Mukherjee, K., Ray, S.C. and Miller, S. (2001) Productivity growth in large US commercial banks: The initial post-deregulation experience, Journal of Banking \& Finance, 25(5), 913-939.

Rappaport, A. (1986) Creating shareholder value: The new standard for business performance, New York. The Free Press, A Division of Macmillan Publishers.

Ray, S.C and Desli, E. (1997) Productivity Growth, Technical Progress, and Efficiency Change in Industrialized Countries: Comment, American Economic Review, 87 (5), 1033-1039.

Shephard, R.W. (1970) Theory of Cost and Production Function, Princeton University Press, Princeton, N.J.

Thanassoulis, E. (2001) Introduction to the Theory and Application of Data Envelopment Analysis, Kluwer Academic Publishers, Netherlands.

Yeh, Q. (1996) The application of data envelopment analysis in conjunction with financial ratios for bank performance evaluation, Journal of the Operational Research Society, 47, 980-988. 